\title{
Self-propagating High Temperature Synthesis of Pink Corundum
}

\author{
Anastasiya Nazarova ${ }^{1}$, Nina Radishevskaya ${ }^{1}$, Nikolay Kasatsky ${ }^{1}$, and Natalia Karakchieva ${ }^{2}$ \\ ${ }^{1}$ Tomsk Scientific Centre SB RAS, Tomsk, Russian Federation \\ ${ }^{2}$ Tomsk State University, Tomsk, Russian Federation
}

\begin{abstract}
Pigments based on pink corundum have been obtained by self-propagating high temperature synthesis in $\mathrm{Cr}_{2} \mathrm{O}_{3}-\mathrm{Al}_{2} \mathrm{O}_{3}-\mathrm{Al}$ system using a small amount of chromium oxide (up to $0.5 \mathrm{wt} \%$ ) in the composition of the green mixture. Absorption bands of pink corundum in visible reflectance spectrum at $\lambda=560 \mathrm{~nm}\left(17850 \mathrm{~cm}^{-1}\right)$ and $400 \mathrm{~nm}\left(25000 \mathrm{~cm}^{-1}\right)$ correspond to electron transitions $\left.{ }^{4} \mathrm{~A}_{2 \mathrm{~g}} \rightarrow{ }^{4} \mathrm{~T}_{2 \mathrm{~g}}{ }^{4} \mathrm{~F}\right)$ and ${ }^{4} \mathrm{~A}_{2 \mathrm{~g}} \rightarrow{ }^{4} \mathrm{~T}_{1 \mathrm{~g}}\left({ }^{4} \mathrm{~F}\right)$. Increasing chrome oxide content to $5 \mathrm{wt} \%$ in initial charge mixture leads to pigment darkening due to inclusions of $\mathrm{Cr}_{2} \mathrm{O}_{3}$. Synthesized pigments can be used as a component of glaze ceramic colors for porcelain.
\end{abstract}

\section{Introduction}

Corundum $\alpha-\mathrm{Al}_{2} \mathrm{O}_{3}$ is a crystalline modification of aluminum oxide of hexagonal symmetry. Corundum lattice represents close hexagonal packing of oxygen ions with insignificant distortions, in which two thirds of octahedral gaps are occupied with aluminum cations. Its structure refers to one of superb compact structure of minerals.

Pure corundum is colorless; however, some coloured forms like rubies and sapphires occur in nature. Coloration is caused by presence of insignificant amount of chromium impurities of d-elements which enable isomorphically replace alumina in its crystalline structure. Pink color of rubies is provided by chromium presence in $\alpha-\mathrm{Al}_{2} \mathrm{O}_{3}$ (up to $0.5 \mathrm{wt} . \%$ ). Sapphires occur in a wide variety of colors. Along with blue sapphires there are different colored forms of them. Nickel, titanium, iron (II, III), and manganese impurities yield yellow, blue, orange and reddish pink colors to crystals, correspondingly $[1,2]$. All corundum forms have extremely high hardness. According to Mohs scale corundum hardness is 9 .

In Table 1 common physicochemical properties of corundum are presented [3].

Table 1. Physicochemical properties of corundum.

\begin{tabular}{|c|c|c|c|c|c|}
\hline \multirow{3}{*}{ Mineral } & $\begin{array}{c}\text { Ionic } \\
\text { radius, } \AA \\
\text { (Pauling } \\
\text { scale) }\end{array}$ & $\begin{array}{c}\text { Density, } \\
\mathrm{g} / \mathrm{cm}^{3}\end{array}$ & $\begin{array}{c}\text { Melting } \\
\text { temperature, } \\
{ }^{\circ} \mathrm{C}\end{array}$ & $\begin{array}{c}\text { Hardness } \\
\text { (Mohs } \\
\text { scale) }\end{array}$ \\
\cline { 2 - 6 } & $\mathrm{Al}^{3+}$ & $\mathrm{O}^{2-}$ & & & 9 \\
\hline Corundum & 0.5 & 1.4 & $3.9 \div 4.0$ & 2050 & 9 \\
\hline
\end{tabular}

Combination of unique properties of corundum such as hardness retained even at temperatures up to $1750^{\circ} \mathrm{C}$, excellent dielectric properties, and chemical resistance make it a perfect material for different applications.
Corundum is used as a raw material in abrasive industry for fabrication of grinding powder and cutting discs in grinding, polishing and cutting machine applications. It is an essential part of technical ceramics, e.g. insulation elements in electronic devices, ionization chambers, vacuum instruments, fittings of heating elements with operation temperature up to $1750^{\circ} \mathrm{C}$. Also clockwork mechanisms are made from corundum.

Transparent forms of colored corundums are used in jewelry production. Colorless synthetic corundum leucosapphire is utilized in radio electronics. Pink powder of corundum is applied as a pigment in composition of lead-free glaze dyes [4].

Colored corundums in the form of crystals are produced by different ways. Well-known are Verneuil method, Czochralski method, Kyropoulos method, Bridgman-Stockbarger technique, crystallization from vapor phase, crystallization from solution and melts, hydrothermal method, and electric furnace melting [5].

Synthetic rubies are produced in Russia, China, Switzerland, France, USA, Germany, Great Britain, and India. Small amount of sapphires is produced in Japan and Israel.

Synthesis of technical materials is usually conducted by ceramic production method at temperatures 1500 $1560^{\circ} \mathrm{C}$, required for completing of full transition lowtemperature forms of alumina oxides in $\alpha-\mathrm{Al}_{2} \mathrm{O}_{3}$ with concurrent sintering of particles and overall mass consolidation. Final annealing of high-density products from corundum ceramics is conducted by heating at temperature $1700^{\circ} \mathrm{C}$ in hydrogen furnace during four hours.

Pink pigment is produced in the furnace at temperature $1500^{\circ} \mathrm{C}$ by burning of alumina mixture with $\mathrm{Cr}_{2} \mathrm{O}_{3}$ in the presence of mineralizer $\left(2\right.$ wt. $\%$ of $\mathrm{H}_{3} \mathrm{BO}_{3}$ ) [4].

\footnotetext{
Corresponding author: cay@sibmail.com
} 
Self-propagating high temperature synthesis (SHS) is not a traditional way of producing ceramic pigments and refractories based on colored corundums. This method is utilized inner chemical energy of system that provides fast conducting of a chemical reaction and presents oneself an example of power-efficient process [6].

The aim of this work is synthesis of pink corundum by self-propagating high temperature method (SHS) and investigating phase composition and structure of the obtained pigment.

\section{Materials and methods}

Pigments were synthesized from $\mathrm{Cr}_{2} \mathrm{O}_{3}$ powder $(>99 \%$ pure, "Urals metal", Yekaterinburg, Russia), $\mathrm{Al}_{2} \mathrm{O}_{3}$ powder ( $>99 \%$ pure, Soyuzkhimprom, Novosibirsk, Russia) and alumina powder (ASD-4, > 99\% pure, LLC Valkom-PM, Volgograd, Russia). Initial components were kneaded thoroughly in a porcelain mortar and after that were placed into the SHS chamber for sintering in flow of argon and oxygen (10\% vol.). During combustion the pressure of oxygen was $11.7 \div 12.7 \mathrm{kPa}$.

For corundum synthesis porous samples of charge mixture were used. Combustion of powder samples were carried out in furnace on the face end of nichrome electric coil. The heat delivered by electric coil initiated chemical reaction owing to generation of combustion wave. Obtained SHS-derived products were milled.

For producing pink corundum alumina oxide represented by mixture of polymorphous modifications was used. Approximate content of polymorphous modifications of alumina oxide is presented in Table 2 .

Table 2. Polymorphous modifications of alumina oxide used for pigment synthesis.

\begin{tabular}{|c|c|c|c|c|c|}
\hline Phase & $\alpha-\mathrm{Al}_{2} \mathrm{O}_{3}$ & $\gamma-\mathrm{Al}_{2} \mathrm{O}_{3}$ & $\eta-\mathrm{Al}_{2} \mathrm{O}_{3}$ & $\theta-\mathrm{Al}_{2} \mathrm{O}_{3}$ & $\chi-\mathrm{Al}_{2} \mathrm{O}_{3}$ \\
\hline $\begin{array}{c}\text { Composition, } \\
\text { wt.\% }\end{array}$ & 40 & 11 & 24 & 17 & 8 \\
\hline
\end{tabular}

Calculations have been done with demo version of Match software and PDF-2 and Fityk database application. Table 2 shows that the main part of alumina oxide consists of its low-temperature modifications.

The crystalline phase of obtained pigments were identified by powder X-ray diffraction (DRON-UM, filtered Co $\mathrm{K}_{\alpha}$-emission) and infrared spectroscopy technique with Fourier transform infrared spectrometer (FTIR) (Thermo Electron Corporation, Nicolet 5700) in the range of $4000-400 \mathrm{~cm}^{-1}$.

Microstructure of SHS-derived products were studied by optical spectroscopy technique with inverted microscope (Carl Zeiss Axiovert 200M). Inorganic pigments based on the pink corundum were subjected to UV-visible spectrophotometry investigation (Thermo Electron Corporation, Evolution 600) equipped with diffuse reflectance accessory.

\section{Results and discussions}

Pink corundum was synthesized by SHS using the $\mathrm{Al}_{2} \mathrm{O}_{3}$, $\mathrm{Cr}_{2} \mathrm{O}_{3}$ and $\mathrm{Al}$ powders.

The main reaction in SHS of pink pigment is reaction of alumina oxidation through aluminothermic reaction:

$$
\mathrm{Cr}_{2} \mathrm{O}_{3}+2 \mathrm{Al}+\mathrm{O}_{2}=\mathrm{Al}_{2} \mathrm{O}_{3}+2 \mathrm{CrO}+444.6 \mathrm{~kJ}
$$

The initial component $\mathrm{Al}_{2} \mathrm{O}_{3}$ was used as an inert substance.

Figures 1a-c present microphotographs of pink corundum $\mathrm{Cr}_{2} \mathrm{O}_{3}-\mathrm{Al}_{2} \mathrm{O}_{3}$. It is seen that absence of chromium inclusions in metallographic sample of pigment indicates that reduction reaction does not occur completely.
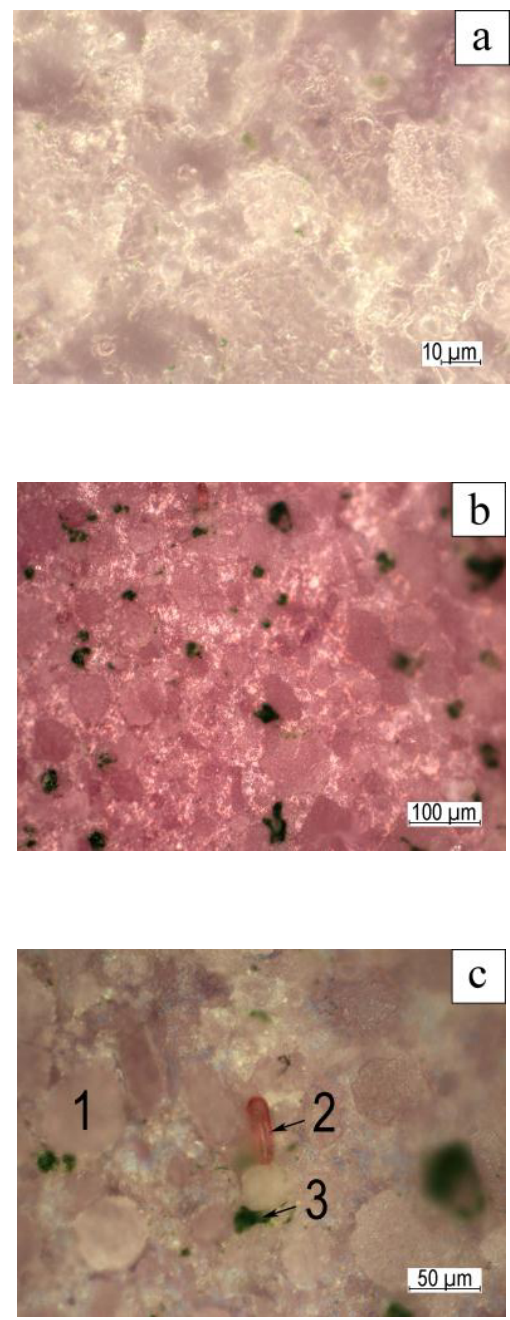

Fig. 1 a, b, c. Microphotographs of pink corundum $\mathrm{Cr}_{2} \mathrm{O}_{3}-\mathrm{Al}_{2} \mathrm{O}_{3}$ (Axiovert 200M): a) - 0,5 wt.\% $\mathrm{Cr}_{2} \mathrm{O}_{3}$, в) - 5 wt. $\% \mathrm{Cr}_{2} \mathrm{O}_{3}$, c) - 1 wt. $\% \mathrm{Cr}_{2} \mathrm{O}_{3},(1)$ - pink corundum; (2) - large crystal; (3) - $\mathrm{Cr}_{2} \mathrm{O}_{3}$.

As a result of $\mathrm{Cr}_{2} \mathrm{O}_{3}$ reduction reaction, the formation of $\mathrm{CrO}$ occurs, which is more stable oxide at high temperatures. Binding energy $\mathrm{E}$, calculated for $\mathrm{CrO} / \mathrm{Cr}_{2} \mathrm{O}_{3}$ according to Born-Haber cycle [7], for chromium monoxide is higher than for chromium oxide(III): $\left(\mathrm{E}_{\mathrm{Cr} 2 \mathrm{O} 3}=805 \mathrm{~kJ} / \mathrm{mol}, \mathrm{E}_{\mathrm{CrO}}=1020 \mathrm{~kJ} / \mathrm{mol}\right)$.

Increasing of $\mathrm{Cr}_{2} \mathrm{O}_{3}$ in initial charge mixture leads to darkening of pigment (Figure 1b). Increasing of $\mathrm{Cr}_{2} \mathrm{O}_{3}$ 
higher than 5 wt.\% causes to occurrence of $\mathrm{Cr}_{2} \mathrm{O}_{3}$ inclusions in corundum structure after self-propagating high temperature synthesis. As shown in Figures 1 (a, b, c,) corundum has granular structure. Small crystals of red color - ruby - can be found (Figure 1c).

Figure 2 presents XRD patterns of pink pigment. Xray diffraction analyses showed that there are some reflections which are typical only for corundum.

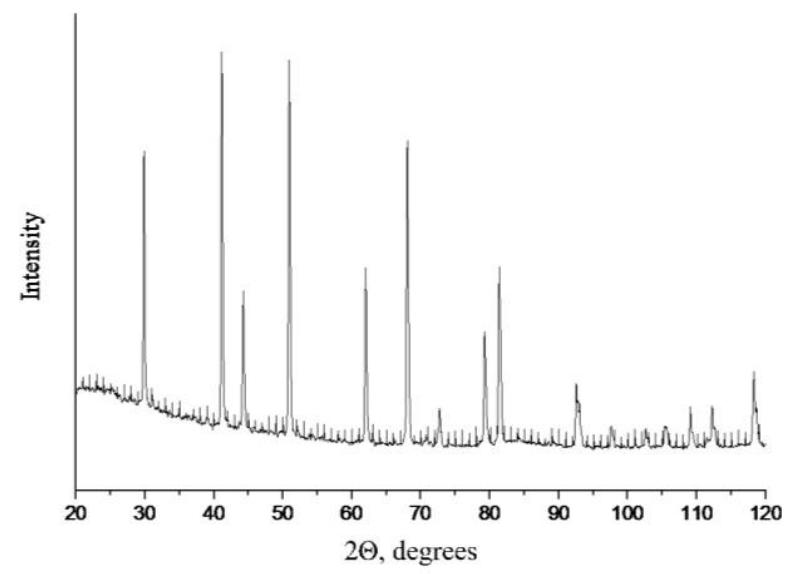

Fig. 2. XRD patterns of pink corundum.

Figure 3 shows reflectance spectra of pink corundum in visible region.

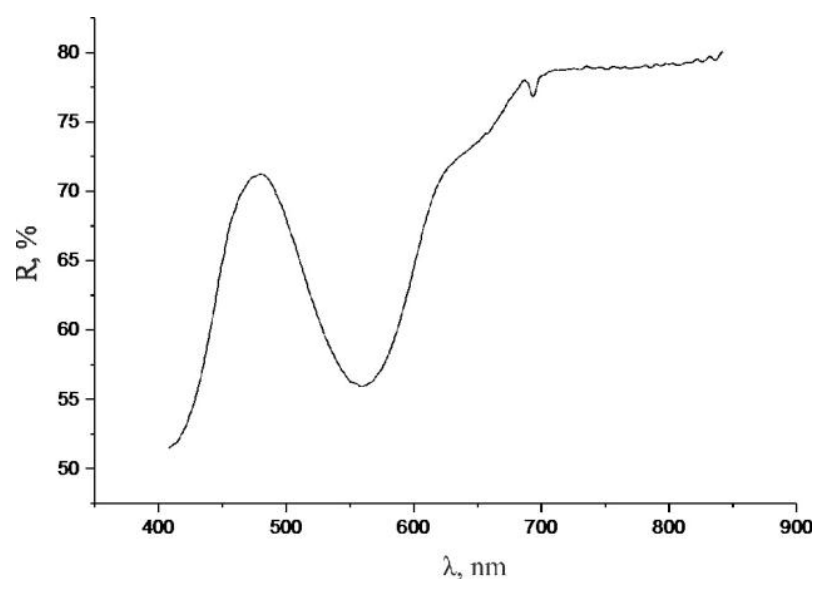

Fig. 3. Reflectance spectra of pink corundum $\left(\mathrm{Cr}_{2} \mathrm{O}_{3}\right.$ $\mathrm{Al}_{2} \mathrm{O}_{3}$ system) in visible region of $40-850 \mathrm{~nm}$.

There are two absorption bands at $\lambda=560 \mathrm{~nm}(17850$ $\left.\mathrm{cm}^{-1}\right)$ and $400 \mathrm{~nm}\left(25000 \mathrm{~cm}^{-1}\right)$ in reflectance spectrum of pink pigment that correspond to electron transitions ${ }^{4} \mathrm{~A}_{2 \mathrm{~g}} \rightarrow{ }^{4} \mathrm{~T}_{2 \mathrm{~g}}\left({ }^{4} \mathrm{~F}\right)$ and ${ }^{4} \mathrm{~A}_{2 \mathrm{~g}} \rightarrow{ }^{4} \mathrm{~T}_{1 \mathrm{~g}}\left({ }^{4} \mathrm{~F}\right)$, and determine intensive pink color of pigment.

Ingress of $\mathrm{Cr}^{3+}$ ion impurities into Al-octahedrons that have less size than Cr-octahedrons causes decreasing of chemical bond length between $\mathrm{Cr}^{3+}$ and $\mathrm{O}^{2-}$ due to compression. Ion crystal-chemical radiuses (according to Pauling) for $\mathrm{Cr}^{3+}$ and $\mathrm{Al}^{3+}$ are 0.64 and 0.5 $\AA$, correspondingly. This leads to increasing of ligand disintegration energy field and transition from green color to red one.

FTIR spectroscopy data analysis according to [9, 10] for obtained pink pigment $\left(0,5\right.$ wt. $\left.\% \mathrm{Cr}_{2} \mathrm{O}_{3}\right)$ showed that as a result of SHS, formation of corundum structure occurs which is proved by absorption bands at $\sim 457.4$ $\mathrm{cm}^{-1}, 606.7 \mathrm{~cm}^{-1}$ and $643.1 \mathrm{~cm}^{-1}$, typical for corundum phase. It is known that all polymorphic modifications $\left(\mathrm{Al}_{2} \mathrm{O}_{3}\right)$ containing in the aluminum oxide powder become $\alpha-\mathrm{Al}_{2} \mathrm{O}_{3}$ at the temperatures of $1000-1100{ }^{\circ} \mathrm{C}$ [8]. The increased content of $\mathrm{Cr}_{2} \mathrm{O}_{3}(0.5 \mathrm{wt} \%)$ in the initial reagents leads to a shift of absorption bands up to $476.6 \mathrm{~cm}^{-1}, 557.5 \mathrm{~cm}^{-1}$ and $628.2 \mathrm{~cm}^{-1}$.

However, there are absorption bands for the values of $718.6 \mathrm{~cm}^{-1}$ and $1083.6 \mathrm{~cm}^{-1}$, which are typical for tetrahedrally coordinated aluminum $\left[\mathrm{AlO}_{4}\right]$ in the spinel $\left[\mathrm{AlO}_{4}\right]\left[\mathrm{CrO}_{6}\right]$ and in the groups $\left[\mathrm{AlO}_{4}\right]\left[\mathrm{AlO}_{6}\right]$, indicating that in high-speed SHS processes, not all tetrahedrally coordinated aluminum with lowtemperature modifications became octahedrally coordinated (Figure 4).

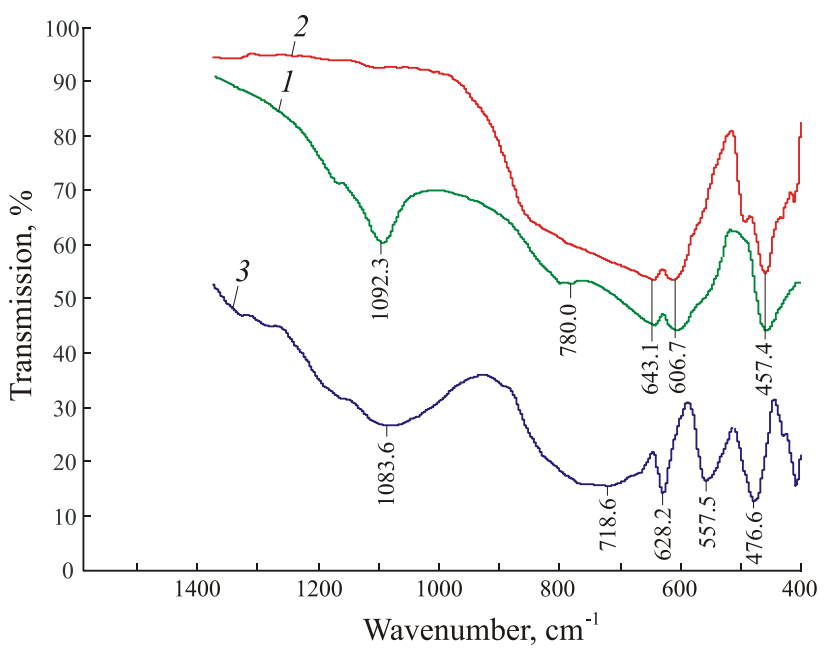

Fig. 4. IR spectra corundum: 1 - grey corundum, 2 pink corundum $\left(0,5\right.$ wt. $\left.\% \mathrm{Cr}_{2} \mathrm{O}_{3}\right), 3$ - pink corundum (5 wt. $\% \mathrm{Cr}_{2} \mathrm{O}_{3}$ ).

When the content of $\mathrm{Cr}_{2} \mathrm{O}_{3}$ oxide is high ( $\geq 5$ wt.\% $\left.\mathrm{Cr}_{2} \mathrm{O}_{3}\right)$ in the green mixture, high temperatures, the reducing behavior and speed of the SHS process can contribute to the formation of the $\mathrm{Cr}_{2}+\mathrm{Al}_{2} \mathrm{O}_{4}$ spinel, as evidenced by the absorption band $\left[\mathrm{AlO}_{6}\right]$ in spinels for $557.5 \mathrm{~cm}^{-1}$. This absorption band can be associated with the aluminum oxide $\mathrm{AlAl}_{2} \mathrm{O}_{4}$ having a spinel structure and described in [11]. The fluctuations of the bonds $\left[\mathrm{Cr}^{2}\right.$ $\left.{ }^{+} \mathrm{O}_{4}\right]$ overlap on that of the group $\left[\mathrm{AlO}_{4}\right]$. Consideration of the available aluminate spinel $\mathrm{AlAl}_{2} \mathrm{O}_{4}$ allows us to assume that the metastable chrome spinel $\mathrm{SrCr}_{2} \mathrm{O}_{4}$ is formed, but it is immediately oxidized to $\mathrm{Cr}_{2} \mathrm{O}_{3}$ [11]. In the oxygen environment, $\mathrm{Cr}^{2+}$ is oxidized to $\mathrm{Cr}^{3+}$. The shift of the absorption band to the high frequency region from $457.4 \mathrm{~cm}^{-1}$ to $476.6 \mathrm{~cm}^{-1}$ indicates the strengthening of Al-O -bond for the octahedrally coordinated aluminum in corundum due to the substitution of the $\mathrm{Al}^{3+}$ cations in the lattice by the larger $\mathrm{Cr}^{3+}$ cations. The absorption bands are not observed in the range of $\sim 890-900 \mathrm{~cm}^{-1}$, indicating that $\left[\mathrm{Cr}^{6+} \mathrm{O}_{4}\right]$ is not formed [12].

Pigment annealing at temperature $1500^{\circ} \mathrm{C}$ does not lead to changing of color, which allows using it as a component of glaze ceramic colors for porcelain. 


\section{Conclusion}

Pink pigments were obtained in $\mathrm{Cr}_{2} \mathrm{O}_{3}-\mathrm{Al}_{2} \mathrm{O}_{3}$ system by self-propagating high temperature synthesis. X-ray diffraction analyses data showed that pigment has corundum structure. Absorption bands of pink corundum in visible region of reflectance spectrum at $\lambda=560 \mathrm{~nm}$ $\left(17850 \mathrm{~cm}^{-1}\right)$ and $400 \mathrm{~nm}\left(25000 \mathrm{~cm}^{-1}\right)$ correspond to electron transitions ${ }^{4} \mathrm{~A}_{2 g} \rightarrow{ }^{4} \mathrm{~T}_{2 g}\left({ }^{4} \mathrm{~F}\right)$ and ${ }^{4} \mathrm{~A}_{2 g} \rightarrow{ }^{4} \mathrm{~T}_{1 g}\left({ }^{4} \mathrm{~F}\right)$. Pink color of pigment is caused by ion substitution of $\mathrm{Al}^{3+}$ in $\alpha-\mathrm{Al}_{2} \mathrm{O}_{3}$-octahedron with $\mathrm{Cr}^{3+}$ ions. Increasing of chromium oxide in charge mixture higher than 5 wt.\% leads to darkening of pigment due to formation of inverted spinel and $\mathrm{Cr}_{2} \mathrm{O}_{3}$ inclusions. Synthesized pink pigments can be used as a component of glaze ceramic colors for porcelain.

\section{References}

1. B.Estifanos, K.Stahl, R.G. Andreassov, G.Bylang, A mineralogical and structural study of red corundum $\mathrm{Al}_{1.98} \mathrm{Cr}_{0.02} \mathrm{O}_{3}$ from Froland, Norway, Norsk Geologisk Tidsskrift,77, 119 (1997)

2. J.M. Duroc-Danner, Untreated yellowish orange sapphire exhibiting its natural color, The Journal of Gemology, 5-8, 174 (2011)

3. G.V. Samsonov, T.G. Bulankova, F.L. Burykina, T.N. Znatokova, etc. Physical and chemical properties of oxides. Reference book (in Russian), (Metallurgy, Moscow, 456, 1969)

4. G.N. Maslennikova, I.V. Pitzh, Ceramic Pigments (in Russian), (Stroymaterialy, Moscow, 224, 2009)

5. G.N. Ivanova, Synthetic analogous of jewelry gems (in Russian), (Irkutsk University, Irkutsk, 115, 2006)

6. A.S. Rogachev, A.S. Mukasyan, Combustion for material synthesis: introduction to macrokinetics (in Russian), (Phyzmatlit, Moscow, 400, 2013)

7. N.P. Lyakishev, Yu. L. Pliner, G.F. Ignatenko, S.I. Lappo, Aluminothermy (in Russian), (Metallurgy, Moscow, 424, 1978)

8. A.B. Nikol'sky, Physical method of inorganic materials investigation (in Russian), (Akdemiya, Moscow, 448, 2006)

9. R.Yu. Zinyuk, A.G. Balykov, I.B. Gavrilenko, A.M. Shevyakov, FTIR-spectroscopy in inorganic technology (in Russian), (Khimiya, Leningrad, 160, 1983)

10.K.V. Chernyakova, I.A. Vrublevskii, M.I. Ivanovskaya, D.A. Kotikov, Impurity defective structure of anodic alumina oxide produced by method of two-sided anodic oxidation in solution of tartaric acid, Journal of Applied Spectroscopy (in Russian), 1, 83 (2012)

11. Horoshavin L.B. Spinel Firebriks. (Ekaterinburg, Ural Branch RAS, 600, 2009).

12. Barabanov V.F. Modern Physical Methods in Geochemistry. (Leningrad State University, 391, 1990) 